DOI: https://doi.org/10.24127/ajpm.v10i4.4134

\title{
KEMAMPUAN PEMAHAMAN GEOMETRI DALAM E-LEARNING DI MASA COVID 19
}

\author{
Muhamad Firdaus ${ }^{1}$, Hodiyanto ${ }^{2 *}$ \\ ${ }^{1,2 *}$ Pendidikan Matematika, IKIP PGRI Pontianak, Indonesia \\ *Corresponding author. \\ E-mail: $\quad$ kiranafirdiani@gmail.com ${ }^{1)}$ \\ $\left.\underline{\text { hodivanto@ikippgriptk.ac.id }}^{2} *\right)$
}

Received 21 August 2021; Received in revised form 16 November 2021; Accepted 21 December 2021

\begin{abstract}
Abstrak
Tujuan penelitian ini adalah untuk mengetahui: (1) respon mahasiswa mahasiswa terhadap perkulaiahan daring (dalam jaringan) atau e-learning, serta kendala yang dialami mahasiswa selama mengikuti pembelajaran daring dalam pembelajaran geometri, (2) kemampuan pemahaman geometri mahasiswa setelah mengikuti pembelajaran daring. Metode penelitian menggunakan metode penelitian kualitatif, berupa studi kasus. Alat pengumpul data yang digunakan adalah angket, tes kemampuan pemahaman dan lembar wawancara. Subjek yang mengisi angket respon mahasiswa terhadap perkulaiahan daring (dalam jaringan) sebanyak 49 orang mahasiswa Program Studi Pendidikan Matematika IKIP PGRI tetapi hanya dua orang mahasiswa terendah yang diambil untuk dilakukan wawancara untuk melihat kemampuan pemahaman geometri. Berdasarkan hasil penelitian dapat disimpulkan bahwa (1) mahasiswa lebih suka belajar tatap muka dari pada mengikuti perkuliahan online selama satu semester. Banyak sekali kendala mahasiswa selama mengikuti pembelajaran: jaringan yang tidak memadai bahkan banyak di daerahdaerah yang tidak ada signal/jaringan, sulitnya memahami dalam pembelajaran daring, kehabisan kuota, mahalnya harga kuota bagi keluarga tidak mampu, ketidakmampuan orang tua untuk membeli android, jaringan terganggu bahkan hilang pada saat bencana, dan tugas yang menumpuk yang diberikan oleh dosen, (2) mahasiswa masih kesulitan dalam menyelesaikan soal kemampuan pemahaman khusunya pada indikator pemahaman fungsional.
\end{abstract}

Kata kunci: Covid 19, e-learning; kemampuan pemahaman; kendala e-learning; respon.

\begin{abstract}
The purpose of this study was to determine: (1) student responses during online learning (on the network) or e-learning, and obstacles experienced by students during online learning (on the network) in learning geometry, (3) ability to understand geometry students after participating in online learning. The research method uses qualitative research methods, in the form of case studies. The data collection tools used were questionnaires, comprehension ability tests and interview sheets. Subjects filling out a response questionnaire to e-learning were 49 students of the Mathematics Education Study Program of IKIP PGRI but only the lowest two students were taken for interviews to see their ability to understand geometry. Based on the results of the study, it can be concluded that (1) students prefer to study face-to-face rather than taking online lectures for one semester. There are many obstacles experienced by students while participating in learning such as: inadequate networks, even many in areas that are not no signal/network, difficulty understanding online learning, running out of quota, high quota prices for underprivileged families, inability of parents to buy androids, disrupted networks and even lost during disasters, and piling up assignments given by lecturers, (2) students it is still difficult to solve the problem of understanding ability, especially on indicators of functional understanding.
\end{abstract}

Keywords: Covid 19; e-learning; e-learning constraints; response; understanding ability.

This is an open access article under the Creative Commons Attribution 4.0 International License 
DOI: https://doi.org/10.24127/ajpm.v10i4.4134

\section{PENDAHULUAN}

Kemampuan pemahaman adalah kemampuan yang seharusnya dimilki oleh peserta didik baik siswa maupun mahasiswa. Hal ini bersesuaian dengan tujuan pembelajaran matematika pada kurikulum 2013 (Permendikbud, 2018). Pentingnya pemahaman matematis ini mengharuskan guru maupun dosen agar menjadikan tujuan utama yang ingin dicapai dalam pembelajaran karena jika kemampuan pemahaman peserta didik rendah maka mereka secara otomatis tidak akan mampu menyelesaikan permasalahan yang menuntut berpikir tingkat tinggi. Oleh sebab itu, kemampuan pemahaman menjadi kemampuan dasar/utama yang harus dimiliki oleh siswa mapun mahasiswa.

Kemampuan

pemahaman

geometri khususnya geometri analitik bidang (GAB) menjadi penting karena materi tersebut berkaitan satu sama lain dan biasanya menjadi syarat untuk mengambil mata kuliah geometri analitik ruang (GAR). Jadi bagaimana mahasiswa memahami GAR jika mereka masih belum memahasi GAB.

Kemampuan pemahaman tidak hanya sekedar mengingat kembali pengalaman dan menyatakan kembali apa yang pernah dipelajari (Kristanti et al., 2019). Tetapi kemampuan pemahaman lebih dari sekedar mengetahui dan mengingat sehingga tujuan pembelajarab tercapai dan belajar lebih bermakna. Kemampuan pemahaman matematis merupakan salah satu hard skill yang harus dimiliki peserta didik (Sumarmo, 2010b). Adapun indikator kemampuan pemahaman yang digunakan dalam penelitian ini adalah: (1) pemahaman komputasional: mahasiswa dapat menerapkan konsep atau rumus dalam menyelesaikan soal, (2) pemahaman fungsional: mahasiswa dapat menyelesaikan soal yang berkaitan dengan konsep lain (Sumarmo, 2010).

Pada tahun 2019 sudah ada sebuah penelitian yang memperoleh hasil bahwa kemampuan pemahaman mahasiswa dalam mempelajari materi GAB adalah rendah (Hodiyanto \& Santoso, 2019, 2020). Oleh sebab itu, perlu dilakukan penelitian lanjutan dengan kondisi yang berbeda yaitu pada masa pandemi covid 19. Covid 19 telah banyak memakan korban. Wabah tersebut melanda Indonesia sekitar awal Maret 2020 dan sampai saat ini penyebaran virus masih bertambah. Pandemi covid 19 mengakibatkan perubahan kebijakan diberbagai sektor khususnya sektor pendidikan. Kebijakan pemerintah akibat dari pandemi covid 19 meminta masyarakat agar stay at home (work from home/ WFH and study from home/STH) dan physical and social distancing.

Kebijakan WFH and STH berpengaruh dalam dunia pendidikan di Indonesia khususnya dalam proses belajar mengajar yang sebelumnya lebih mengoptimalkan tatap muka. Perubahan ini tentu memberikan pengaruh terhadap kebiasaan, perilaku dan proses pembelajaran yang sebelumnya jarang dan bahkan tidak pernah dilakukan khususnya di Progrm Studi Pendidikan Matematika IKIP PGRI Pontianak. Padahal kurikulum tetap berlanjut yang artinya perkuliahan atau pembelajaran tetap harus dilaksanakan kecuali ada kebijakan bahwa pada semester genap ini akan diperpanjang sampai pada batas waktu yang tidak ditentukan. Tetapi hal itu sulit untuk dilakukan karena pandemic covid 19 tidak ada yang tahu sampai kapan akan berakhir. Jika hal itu dilakukan maka program yang sudah direncanakan oleh Kemendikbud maupun perguruan tinggi akan sia-sia. Apalagi jika sekolah maupun perguruan 
tinggi tersebut swasta, tentu semua operasional sekolah maupun perguruan tinggi dari siswa maupun mahasiswa. Jadi, jika semester genap ini diperpanjang maka siapa yang akan membayar biaya operasional sekolah maupun perguruan tinggi, honor, gaji para pegawai, guru maupun dosen. Oleh sebab itu, perkuliahan atau pembelajaran tetap berjalan sesuai dengan kurikulum yang sudah dibuat. Tetapi tetap dilaksanakan dari rumah (WFH dan STH).

Akibat dari kebijakan WFH dan STH tersebut, pembelajaran hanya dapat dilakukan dengan cara daring (dalam jaringan) atau memanfaatkan $e$ learning. Pembelajaran daring sebenarnya sering muncul dipermukaan semenjak kehadiran era industri 4.0 yaitu era Revolusi digital dan era disrupsi teknologi. Salah satu ciri dari era industri 4.0 adalah tenaga manusia akan digantikan dengan robot untuk efisiensi dan efektivitas (Ghufron, 2018). Dengan demikian, e-learning adalah salah satu dampak dari era industri 4.0 di mana pembelajaran tidak harus dengan tatap muka tetapi bisa menggunakan daring.

\section{E-learning (electronic learning)} adalah pembelajaran yang dilakukan dengan jarak jauh dan mengkombinasikan prinsip pembelajaran dengan teknologi (Chandrawati, 2010), sedangkan menurut (Moore et al., 2011) pembelajaran daring adalah pembelajaran dengan memanfaatkan internet dan kemampuan dalam menimbulkan berbagai macam interaksi pembelajaran. Banyak media yang dapat digunakan dalam pembelajaran daring atau $e$ learning seperti media social Instagram dan facebook (Kumar \& Nanda, 2019), Schoology, Edmodo, dan Google Classroom, (Enriquez, 2014; Iftakhar, 2016; Sicat, 2015), WhatsApp (So,
2016), dan Video Blog (Vlog) Channel You Tube (Irwandani et al., 2019).

Pada penelitian ini, pembelajaran daring terdiri dari Google Classroom, zoom dan WAG (WhatsApp Group). Perpaduan inilah yang menunjukkan perbedaan penelitian ini dengan penelitian-penelitian sebelumnya. Penggabungan tiga aplikasi ini dilakukan untuk efektivitas dan efisiensi dalam pembelajaran. Kelemahan dari salah satu aplikasi ini ditutupi oleh aplikasi yang lainnya. Seperti untuk pengumpulan tugas lebih efektif jika menggunakan Google Classroom karena sudah disediakan secara lengkap di Google Classroom. Tetapi untuk diskusi akan lebih maksimal menggunakan zoom dan WAG. Zoom bisa interaksi langsung, sedangkan WAG sudah terbiasa dilakukan oleh mahasiswa sehingga sudah sangat familiar dengan mahasiswa. Selain itu, dalam penelitian ini juga ingin didiskripsikan kemampuan pemahaman mahasiswa setelah dilakukan pembelajaran daring.

Adapun tujuan dalam penelitian ini adalah mengetahu: (1) respon atau pendapat mahasiswa dalam pelaksaan pembelajaran daring serta (2) kemampuan pemahaman geometri mahasiswa setelah mengikuti pembelajaran daring. Semenjak wabah covid 19 pembelajaran dilakukan secara daring sehingga hampir selesainya satu semester ini pembelajaran belum pernah dilakukan secara tatap muka. Selain itu, dalam penelitian ini juga ingin diungkap dan dicari apa saja kendala yang dialami mahasiswa selama pembelajaran daring, sehingga hasil ini bisa dijadikan masukan dan perbaikan ke depan dalam melakukan pembelajaran daring. Penelitian ini juga melihat bagaimana kemampuan pemahaman geometri mahasiswa setelah mengikuti pembela- 
jaran ini, sehingga hasil ini juga akan menjadi bahan evaluasi ke depan untuk meningkatkan kemampuan pemahaman geometri siswa dalam menerapkan pembelajaran daring. Oleh sebab itu, ada beberapa alasan mengapa penelitian ini penting untung dilakukan, diantaranya: (1) hazanah perkembangan ilmu pengetahuan, (2) evaluasi pembelajaran ke depan, (3) sebagai penelitian awal dalam penerapan $e$ learning di Program Studi Pendidikan Matematika IKIP PGRI Pontianak.

\section{METODE PENELITIAN}

Metode penelitian dalam penelitian ini menggunakan metode penelitian kualitatif berupa studi kasus. Adapun subjek penelitian yang diambil adalah mahasiswa Program Studi Pendidikan Matematika IKIP PGRI Pontianak yang sedang mengambil mata kuliah geometri analitik bidang. Alat pengumpulan data yang gunakan adalah angket mahasiswa mahasiswa terhadap perkulaiahan daring, tes kemampuan pemahaman, dan lembar wawancara. Prosedur dalam penelitian ini adalah sebagai berikut: (1) pemberian perkuliahan kepada mahasiswa melalui e-learning (zoom, WAG, dan google classroom), (2) diakhir perkuliahan, mahasiswa diberikan angket dan tes kemampuan pemahaman secara daring (google form), (3) melakukan wawancara (WhatsApp), dan menganalisis hasil angket respon, hasil tes kemampuan pemahaman mahasiswa dan hasil wawancara. Tes kemampuan pemahaman diberikan kepada seluruh mahasiswa sebanyak 49 orang, tetapi hanya dua mahasiswa terendah yang diambil untuk dilakukan wawancara. Tahapan analisis data yang dilakukan adalah reduksi data, penyajian data, dan penarikan kesimpulan.

\section{HASIL DAN PEMBAHASAN}

Angket respon siswa

Untuk mendapat data penelitian dalam pembelajaran online digunakan angket respon dengan skala likert. Hasil respon mahasiswa dalam pelaksanaan pembelajaran daring selama covid $19 \mathrm{di}$ semester Genap akan dipaparkan sebagai berikut:

Kesiapan sistem pendukung berupa server dalam e- learning

Angket dalam penelitian ini dari semua gambar yang ditampilkan, menggunakan pilihan sangat tidak setuju dengan kode/simbol 1, tidak setuju dengan kode/simbol 2, ragu-ragu dengan kode/simbol 3 setuju, dan sangat setuju dengan kode/simbol 4. Gambar 1 menampilkan persentase server dan sistem jaringan.
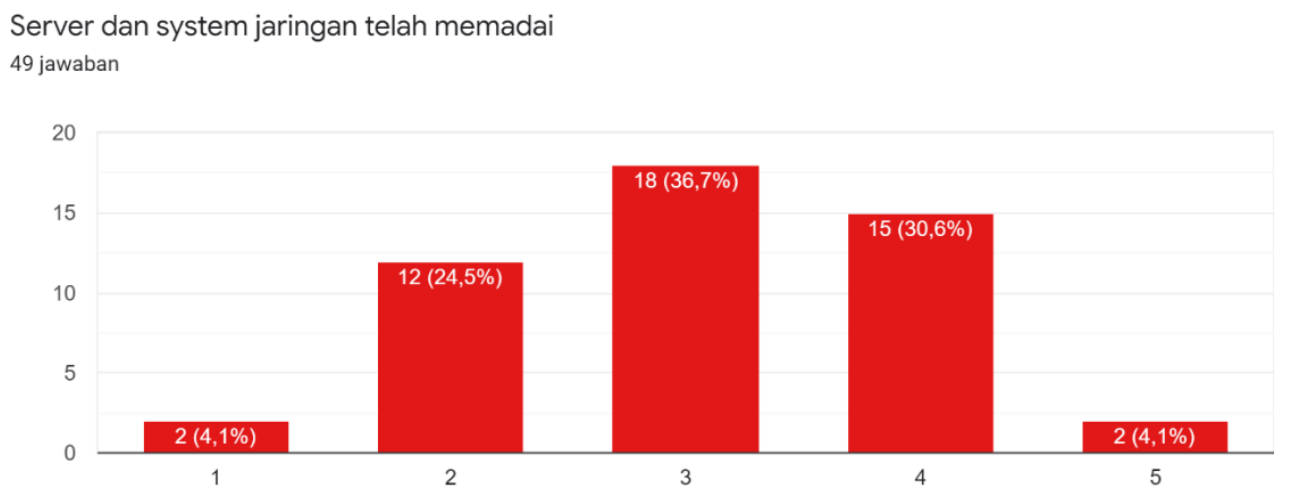

Gambar 1 Persentasi server jaringan telah memadai 
DOI: https://doi.org/10.24127/ajpm.v10i4.4134

Pada Gambar 1 dapat dilihat hasil respon mahasiswa terhadap pembelajaran daring dalam aspek persentasi server jaringan telah memadai. Dari hasil angket ini menunjukkan bahwa hanya $34,7 \%$ untuk jaringan mahasiswa dalam pembelajaran on line sudah tersedia karena mahasiswa yang mengikuti kuliah on line ini $95 \%$ ada di daerah atau di luar Pontianak. Ini menunjukkan 65,3\% mahasiswa beranggapan bahwa ketersediaan jaringan belum maksimal.

Alasan mahasiswa mengikuti perkuliahan daring/online

Salah satu alasan mengikuti perkuliahan daring adalah karena pemanfaatan iptek. Hal ini terlihat dari hasil pada Gambar 2.

Memanfaatkan IPTEK

49 jawaban

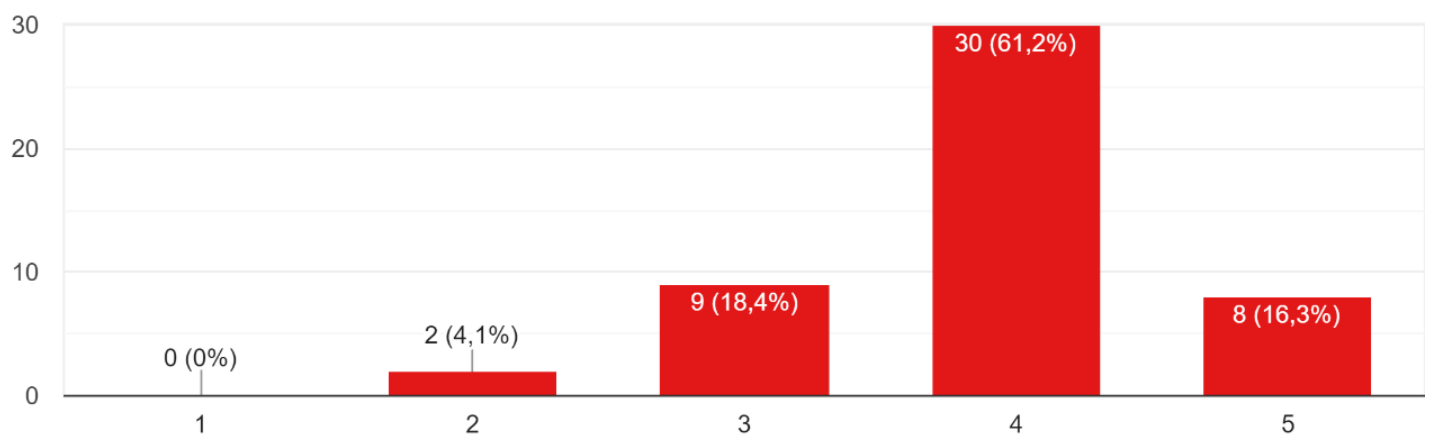

Gambar 2. Persentasi pembelajaran online pemanfaatan IPTEK

Pada Gambar 2 dapat dilihat hasil respon mahasiswa terhadap pembelajaran daring dalam aspek alasana mahasiswa mengikuti pembelajaran online untuk memfaatkan Iptek. Hasil tersebut menunjukkan bahwa $77,5 \%$ mahasiswa setuju dan sangat setuju bahwa pembelajaran online pada masa pandemi covid 19 adalah salah satu pemanfaatan Iptek karena tidak bisa mengikuti pembelajaran tatap muka secara langsung. Berikutnya ada pula hasil yang menunjukkan keikutsertaan dalam pembalajaran daring karena terpaksa dan tidak ada cara lain untuk kuliah selama pandemi covid-19 ditampilkan pada Gambar 3.

Terpaksa ikut karena tidak ada cara lain untuk kuliah selama covid 19.
49 jawaban

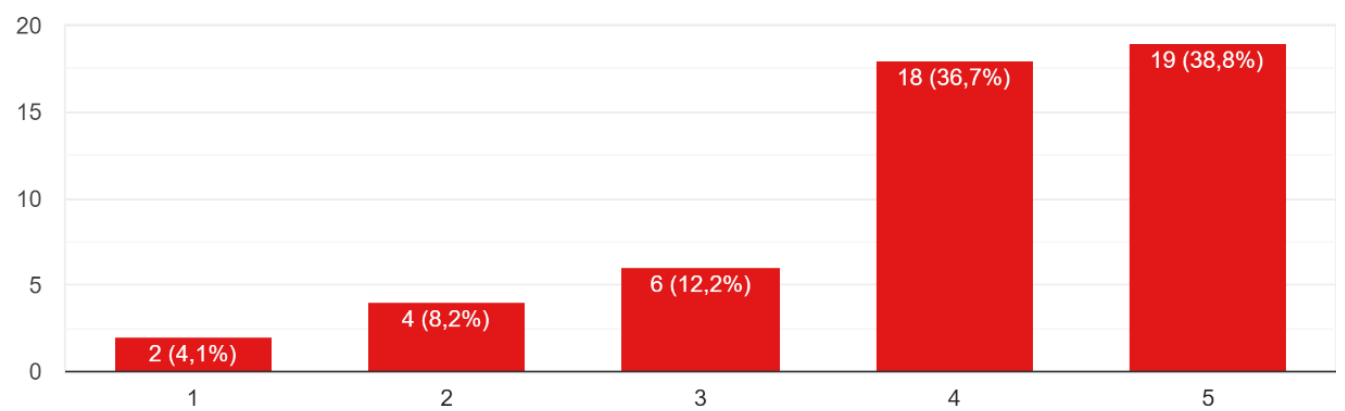

Gambar 3. Persentasi mengikuti pembelajaran online karena tidak ada cara lain 
DOI: https://doi.org/10.24127/ajpm.v10i4.4134

Pada gambar 3 dapat dilihat hasil respon mahasiswa terhadap pembelajaran daring dalam aspek mengikuti e-learning karena memang tidak ada cara lain dalam menyampaikan materi perkuliahan selain pembejarangan daring selama pandemi covid 19. Hasil tersebut menunjukkan bahwa sebanyak 75,5\% mahasiswa setuju dan sangat setuju bahwa mengikuti pembelajaran online karena tidak ada cara lain yang bisa dilakukan dalam pembelajaran. Hasil angket ini menunjukkan bahwa 75,5\% mahasiswa berharap perkuliahan bisa dilaksanakan secara tatap muka karena mereka berpendapat terpaksa mengikuti perkuliahan daring.

Tanggapan Mahasiswa Terhadap
Pembelajaran Daring
Penelitian juga memberikan
angket kepada mahasiswa terkait
tanggapan mahasiswa dalam
pelaksanaan e-learning dan hasilnya
bisa dilihat pada gambar 4, gambar 5,
gambar 6, gambar 7.
Pembelajaran Daring angket kepada mahasiswa terkait tanggapan mahasiswa dalam pelaksanaan e-learning dan hasilnya gambar 6, gambar 7 .
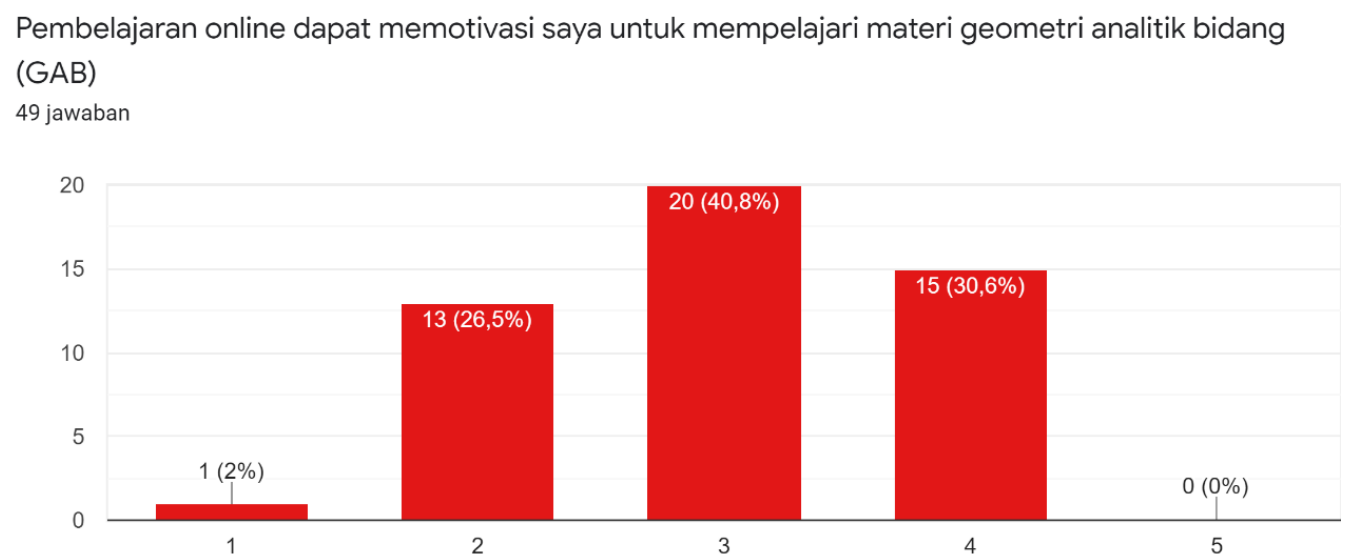

Gambar 4. Persentase e-learning memotivasi mahasiswa
Pada gambar 4 dapat dilihat hasil tanggapan mahasiswa terhadap pembelajaran daring dalam aspek $e$ learning memotivasi mahasiswa. Hasil tersebut menunjukkan hanya 30,6\% mahasiswa yang merasa e-learning memotivasi mahasiswa dalam belajar.
Dengan demikian, 69,4\% mahasiswa beranggapan bahwa pembelajaran daring tidak memotivasi mereka dan ini sesuai dengan pendapat sebelumnya bahwa mereka terpaksan ikut pembelajaran daring karena tidak ada cara lain untuk mengikuti perkuliahan.

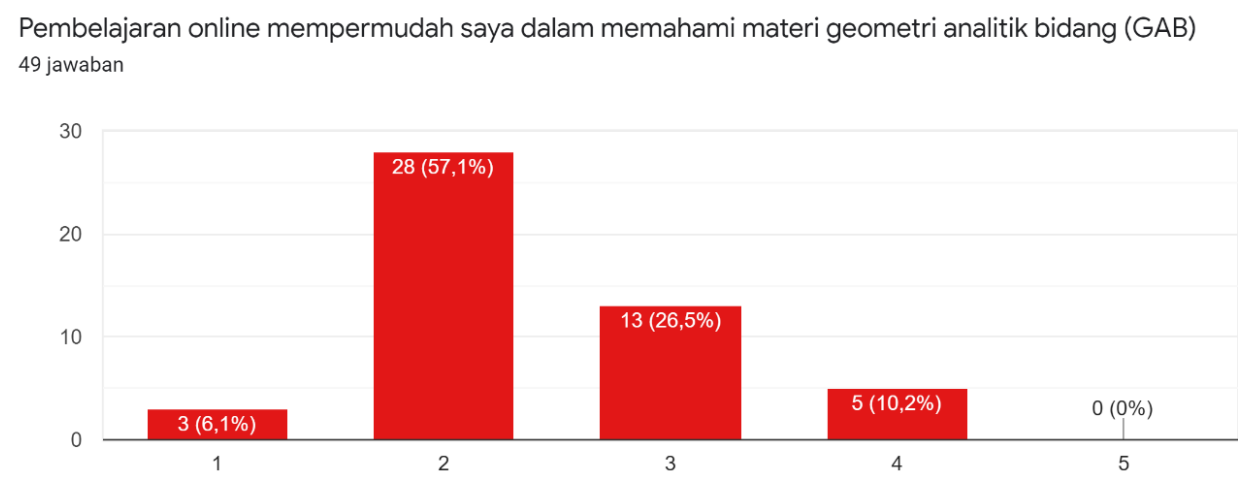

Gambar 5. Persentase e-learning mempermudah mahasiswa memahami materi 
DOI: https://doi.org/10.24127/ajpm.v10i4.4134

Pada gambar 5 dapat dilihat hasil tanggapan mahasiswa terhadap pembelajaran daring dalam aspek pembelajaran online dapat mempermudah mahasiswa memahami materi. Hasil tersebut menunjukkan bahwa hanya $10,2 \%$ mahasiswa yang mudah dalam memahami konsep selama e-learning dan sebaliknya sebanyak $63,2 \%$ mahasiswa berpendapat pembelajaran online dapat tidak mempermudah mahasiswa memahami materi dan sisanya masih ragu-ragu, artinya pembelajaran tatap muka lebih mudah memahami materi yang disampaikan oleh dosen.
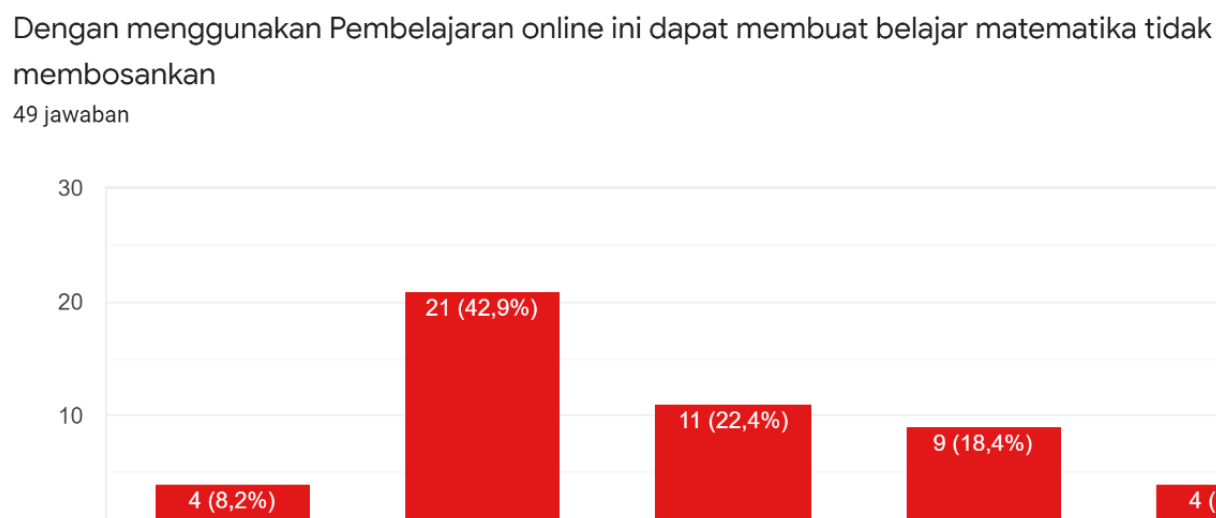
$4(8,2 \%)$ 2

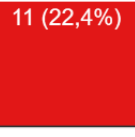

3

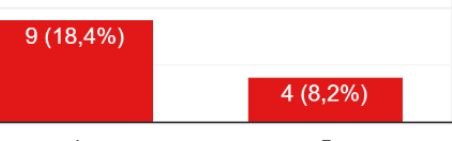

Gambar 6 Persentase e-learning tidak membosankan

Pada Gambar 6 dapat dilihat hasil tanggapan mahasiswa terhadap pembelajaran daring dalam aspek pembelajaran online membuat belajar matematika tidak membosankan. Hasil ini menunjukkan hanya 26,2\% mahasiswa yang beranggapan bahwa pembelajaran matematika dengan online tidak membosankan, sedangkan 51,1\% beranggapan sebaliknya.

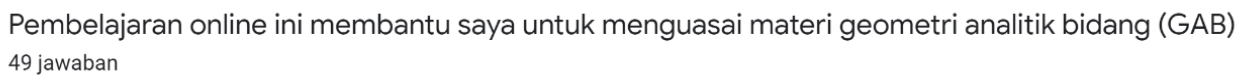

30

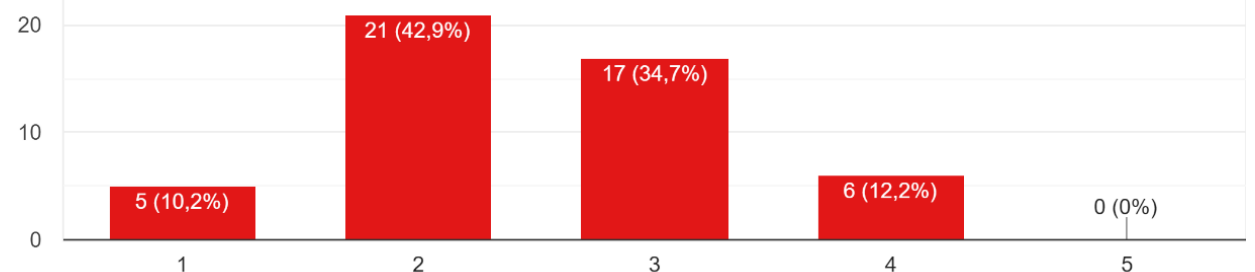

Gambar 7. Persentase e-learning membantu untuk menguasai materi

Dari gambar 7 dapat dilihat hasil tanggapan mahasiswa terhadap pembelajaran daring pada aspek pembelajaran online dapat membantu mahasiswa dalam menguasai materi khususnya materi geometri analitik bidang. Hasil tersebut menunjukkan hanya $12,2 \%$ mahasiswa yang berpendapat bahwa pembelajaran online dapat membantu mahasiswa dalam menguasai materi khususnya materi geometri analitik bidang, sedangkan 
DOI: https://doi.org/10.24127/ajpm.v10i4.4134

$53,1 \%$ mahasiswa berpendapat pembelajaran online tidak dapat membantu mahasiswa dalam menguasai materi. Dengan demikian, dapat disimpulkan bahwa mahasiswa lebih mudah memahami materi dengan tatap muka dari pada pembelajaran daring.

\section{Permasalahan dalam E-learning \\ Berikut akan dipaparkan hasil angket permasalaham pembelajaran online pada Gambar 8 dan Gambar 9.}

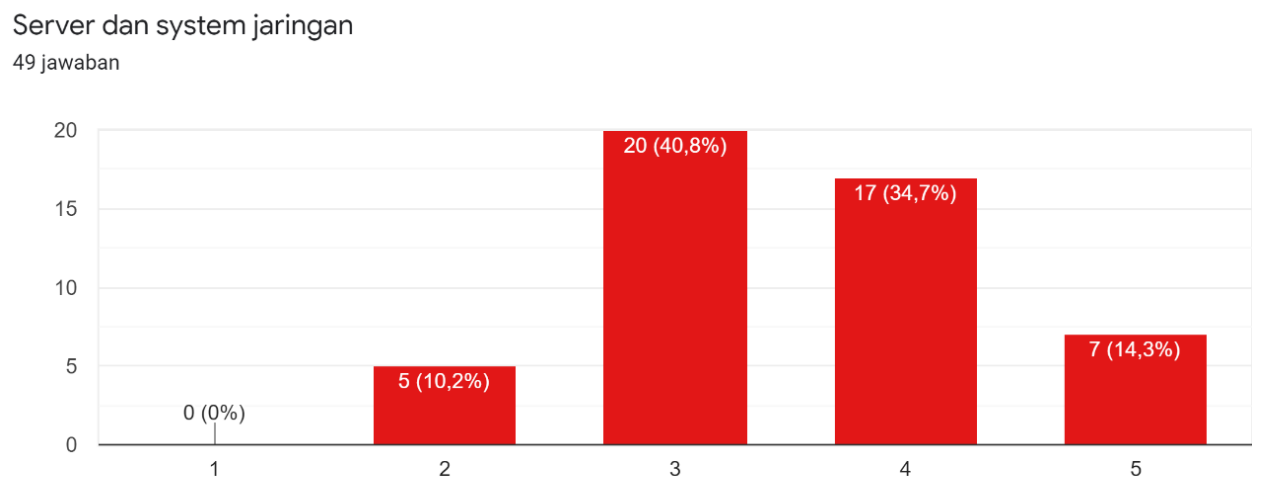

Gambar 8 Persentase permsalahan jaringan

\begin{tabular}{lcllr}
\multicolumn{2}{c}{ Pada Gambar 8 dapat dilihat hasil } & tinggal mahasiswa. Hasil tersebut \\
tanggapan mahasiswa terhadap & menunjukkan $49 \%$ & mahasiswa \\
pembelajaran daring dalam aspek & berpendapat bahwa permasalahan \\
permasalahan terletak pada jaringan & terdapat pada jaringan/server.
\end{tabular}
atau server yang ada di daerah tempat

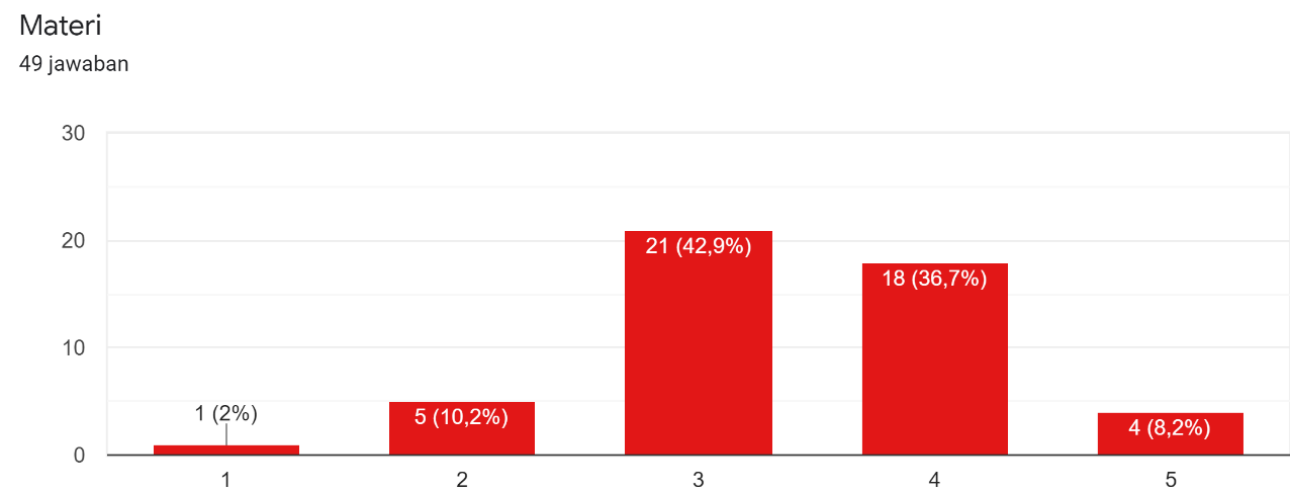

Gambar 9 Persentase Permsalahan Materi

Pada Gambar 9 dapat dilihat hasil tanggapan mahasiswa terhadap pembelajaran daring dalam aspek permasalahan terletak pada materi. Hasil tersebut menunjukkan bahwa
44,9\% mahasiswa berpendapat bahwa permasalahan terletek pada materi pembelajaran. Oleh sebab itu, dapat disimpulkan bahwa selain pembelajaran daring tidak memotivasi mereka 
(membosankan), materi juga dianggap masalah bagi mahasiswa. Dengan demikian, selain meracang pembelajaran daring yang menarik juga materi pembelajaran juga harus dikemas menarik agar mahasiswa termotivasi dan semangat untuk belajar.

\section{Kemampun Pemahaman geometri}

Berikut akan dipaparkan hasil tes kemampuan pemahaman mahasiswa dari dua orang mahasiswa (A1 dan A2) yang memiliki kemampuan pemahaman terendah pada masing-masing indikator tes kemampuan pemahaman pemahaman mahasiswa. Adapun soal pada indikator pemahaman komputasional adalah: Tentukan jarak antara titik A dan B bila koordinat masing-masing secara berurutan adalah A $(1,2)$, B $(6,-10)$ ! Jawaban mahasiswa pada indikator pemahaman komputasional dapat dilihat pada Gambar 10 dan Gambar 11.

\section{$A(1,2)$ dan $B(6,-10)$}

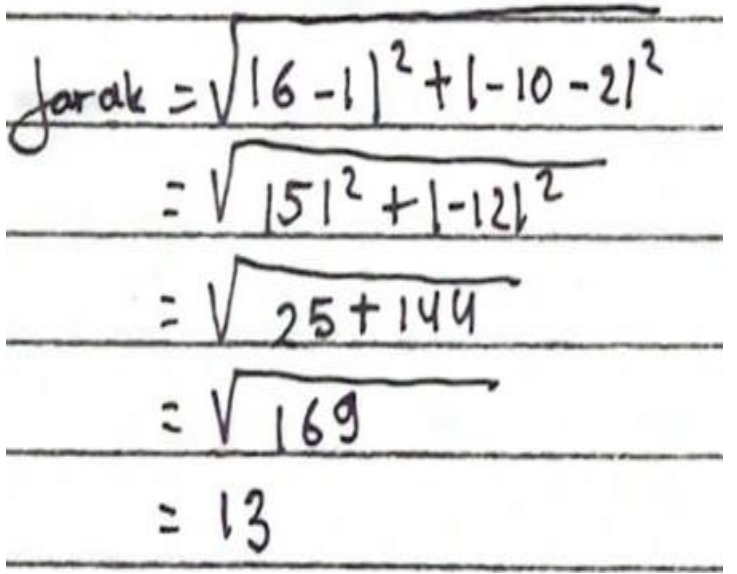

titiktangah:
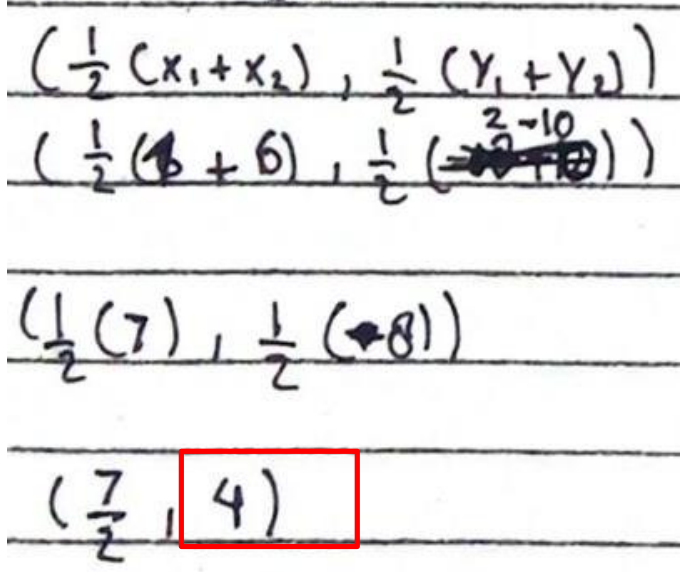

Gambar 10. Hasil tes indikator pemahaman komputasional mahasiswa A1

jarak $A$ dan $B$

$A B=\sqrt{\left|x_{2}-x_{1}\right|^{2}+\left|y_{2}-y_{1}\right|^{2}}$

$=\sqrt{|2-1|^{2}+|-10-6|^{2}}$

$=\sqrt{1^{2}+-16^{2}}$

$=\sqrt{1+256}$

$=\sqrt{257}$

$=16 \sqrt{1}$

$$
\begin{aligned}
& \text { b. Titik tengah } A \text { dan } B \\
& x_{T}=\frac{1}{2}\left(x_{1}+x_{2}\right) \quad y_{T}=\frac{1}{2}\left(y_{1}+y_{2}\right. \\
& x_{T}=\frac{1}{2}(1+2) \quad y_{T}=\frac{1}{2}(6+(-10) \\
& x_{T}=\frac{1}{2}(3) \quad y_{T}=\frac{1}{2}(-4) \\
& x_{T}=1 \frac{1}{2} \quad Y_{T}=-2 \\
& \text { Jad titik tengah antara titik } A \\
& \text { dan Hitk B adalah }\left(1 \frac{1}{2},-2\right)
\end{aligned}
$$

Gambar 11. Hasil tes indikator pemahaman komputasional mahasiswa A2 
Pada gambar 10 diperoleh bahwa jawaban mahasiswa A1 sudah benar dalam menentukan jarak, tetapi masih dalam menentukan titik tengah. Mahasiswa A1 salah dalam menentukan nilai akhir dari y yang seharusnya -4 . Demikian pula dari jawaban mahasiswa A2 pada gambar 11, A2 masih salah dalam menentukan jarak dan titik tengah. Adapun penyebab salah mahasiswa dalam menjawab soal tes kemampuan pemahaman pada indikator pemahaman komputasional akan dianalis dari hasil wawancara pada pembahasan.

Pada indikator pemahaman fungsional mahasiswa dibuatkan dua soal. Soal pertama berkaitan dengan titik tengah dan yang ke dua berkaitan dengan jarak. (1) Diketahui titik pusat lingkaran $\mathrm{P}(3,0)$ dan diketahui pula titik A $(-2,7)$ adalah salah satu titik ujung pada diameter lingkaran tersebut. Tentukanlah koordinat titik ujung lainnya dari diameter tersebut! (2) Diketahui ruas garis dengan titik ujungnya $\mathrm{A}(-5,-6)$ dan $\mathrm{C}(10,1)$. Buktikan bahwa titik B $(4,-2)$ terletak pada ruas garis tersebut atau ketiga titik tersebut kolinier! Jawaban mahasiswa A1 dan A2 pada indikator pemahaman fungsional dapat dilihat pada Gambar 12-Gambar 15.

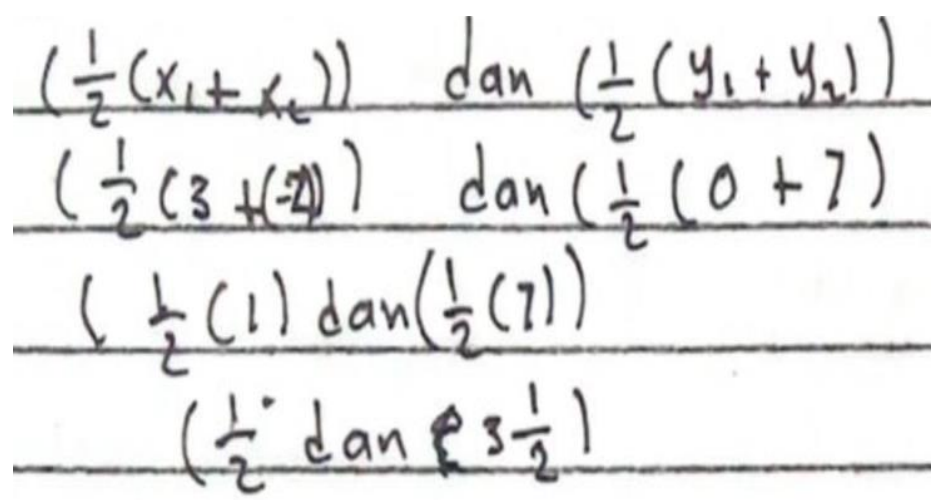

Gambar 12. Hasil tes indikator pemahaman fungsional mahasiswa A1 (nomor 1)

$$
\text { coordinat fitik ujung lainya yaitu }(2,-7)
$$

Gambar 13. Hasil tes indikator pemahaman fungsional mahasiswa A2 (nomor 1)

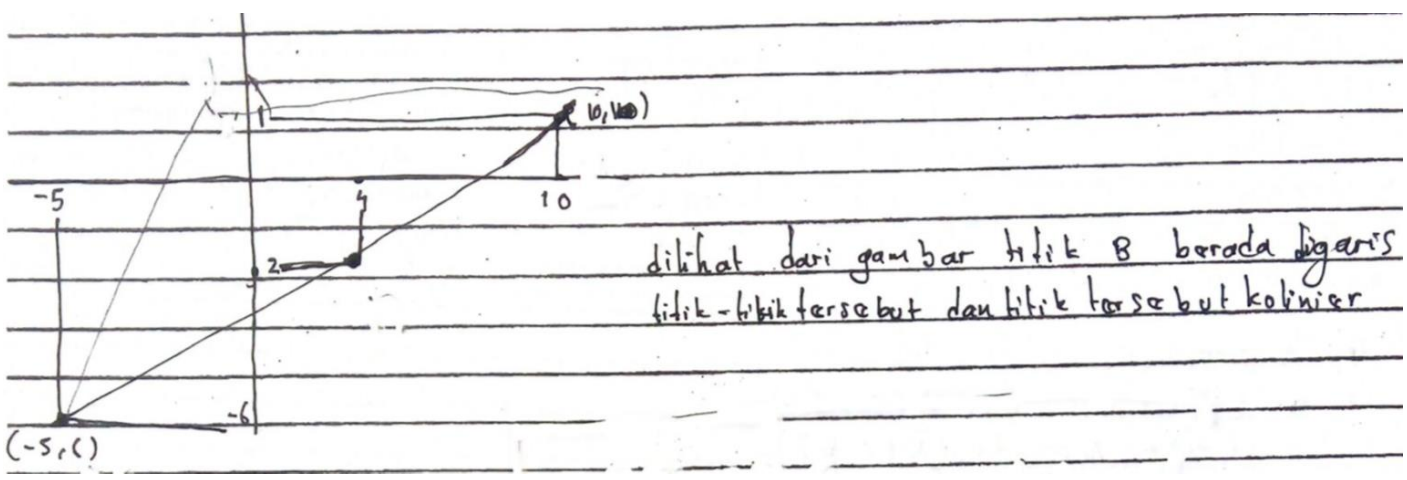

Gambar 14. Hasil tes indikator pemahaman fungsional mahasiswa A1 (nomor 2) 


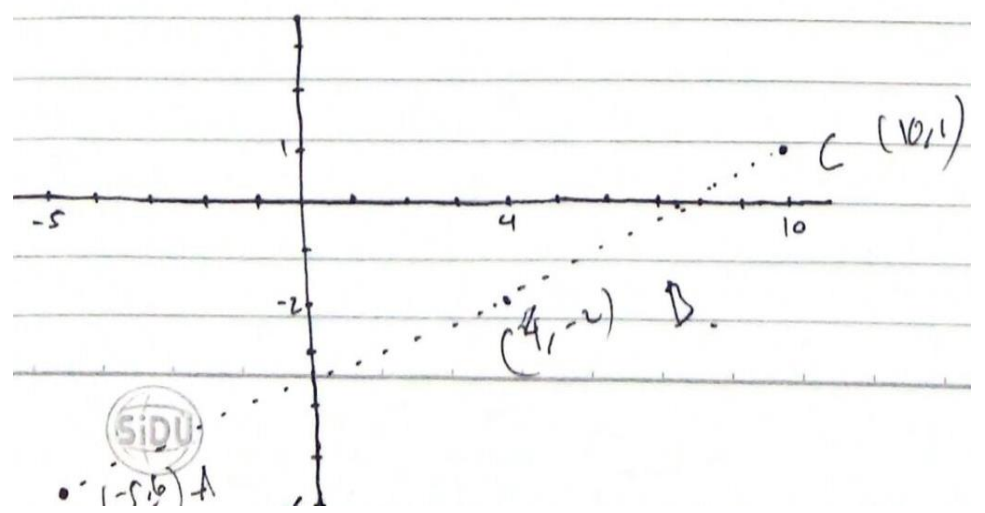

Gambar 15. Hasil tes indikator pemahaman fungsional mahasiswa A2 (nomor 2)

Pada Gambar 12 dan Gambar 13 diperoleh bahwa A1 dan A2 masih salah menjawab soal dalam menentukan koordinat titik ujung lainnya dari diameter tersebut padahal pada soal sudah diketahui titik pusat dan titik A adalah titik ujung lainnya sehingga dengan memanfaatkan rumus titik tengah seharusnya A1 dan A2 bisa menentukan titik ujung lainnya dari diameter lingkaran. Demikian pula soal nomor pada indikator pemahaman fungsional, A2 dan A1 masih salah dalam menyelesaikan soal. Adapun penyebab salahnya mahasiswa dalam menyelesaikan soal indikator pemahaman fungsional akan dianalisis dengan hasil wawancara di pembahasan.

Pada pembahasan ini, jawaban mahasiswa akan dianalisis dengan hasil wawancara. Wawancara dalam penelitian ini dilakukan dengan dua cara yaitu: komentar mahasiswa pada saat mengisi angket dan wawancara via whatsap. Pada pembahasan ini akan dipaparkan berdasarakan hasil penelitian yang diperoleh dan kemudian akan dianalisis dengan menggunakan hasil wawancara.

1. Respon mahasiswa terhadap perkuliahan daring serta kendala yang dialami mahasiswa
Hasil angket menunjukkan bahwa $34,7 \%$ untuk jaringan mahasiswa dalam pembelajaran online sudah tersedia walaupun tidak sekuat jaringan di perkotaan. Dengan demikian, jaringan internet di daerah tempat tinggal mahasiswa masih belum begitu memadai untuk dilaksanakannya $e$ learning. Hal ini didukung dengan hasil wawancara mahasiswa bahwa ada beberapa daerah yang tidak ada jaringan seluler sehingga mahasiswa harus ke Kota Kecamatan atau Kabupaten untuk mendapatkan sinyal dan bahkan ada mahasiswa yang harus naik bukit untuk mendapatkan sinyal. Pembelajaran berbasis online dapat memudahkan mahasiswa dalam mengakses materi dan efisien, tetapi jika jaringan internet tidak memadai maka hal tersebut tidak mungkin bisa tercapai. Laporan Tim Kompas menunjukkan bahwa di beberapa daerah Indonesia menunjukkan bahwa pembelajaran online belum maksimal, terutama di daerah-daerah pelosok dengan jaringan internet yang tidak memadai. 39,90\% penduduk Indonesia yang mengakses internet tahun 2018 (Wahyono et al., 2020). Hasil penelitian Wahyono et al. (2020) mengatakan bahwa keterbatasan jaringan adalah salah satu tantangan dalam pembelajaran online saat ini. 
DOI: https://doi.org/10.24127/ajpm.v10i4.4134

Hasil angket pada aspek pemanfaatan Iptek menunjukkan hasil tersebut menunjukkan bahwa 77,5\% mahasiswa setuju bahwa pembelajaran on line pada masa pandemic covid 19 adalah salah satu pemanfaatan Iptek. Di sisi lain menunjukkan bahwa $75,5 \%$ mahasiswa setuju dan sangat setuju bahwa mengikuti pembelajaran online karena tidak ada cara lain yang bisa dilakukan dalam pembelajaran. Hasil angket ini menunjukkan bahwa 75,5\% mahasiswa berharap perkuliahan bisa dilaksanakan secara tatap muka karena mereka berpendapat terpaksa mengikuti perkuliahan daring. Selain itu, hanya $30,6 \%$ mahasiswa yang merasa $e$ learning memotivasi mahasiswa dalam belajar. Hasil tersebut didukung dengan hasil wawancara peneliti bahwa mahasiswa lebih suka belajar tatap muka. Tetapi boleh sekali-kali melakukan pembelajaran online agar pembelajaran bervariasi. Oleh sebab itu, pembelajaran selama satu semester dengan online tidak membuat mahasiswa lebih termotivasi. Hasil penelitian Dewi (2020) dan Wahid et al. (2020) pembelajaran daring masih kurang efektif jika dibandingkan dengan pembelajaran tatap muka. Hasil penelitian Jamaluddin et al. (2020) menyebutkan bahwa hanya $50 \%$ menyatakan bahwa pembelajaran online mempermudah proses pembelajaran tetapi sisanya menyatakan pembelajaran online tidak mempermudah proses pembelajaran.

Hasil penelitian menunjukkan hanya $10,2 \%$ mahasiswa yang merasa mudah dalam memahami konsep selama e-learning, $\quad 26,2 \%$ mahasiswa berpendapat bahwa pembelajaran matematika dengan online tidak membosankan, dan hanya 12,2\% mahasiswa yang setuju bahwa pembelajaran online dapat membantu mahasiswa dalam menguasai materi khususnya materi geometri analitik bidang. Hasil tersebut diperkuat dengan hasil wawancara dengan mahasiwa bahwa mahasiswa merasa kesulitan dalam memahami materi geometri selama e-learning karena geometri butuh ilustrasi atau visualisasi. Ilustrasi atau visualisasi dalam e-learning dapat dilakukan, tetapi tidak maksimal. Hal ini didukung dengan pendapat (Hodiyanto \& Santoso, 2019) dan (Hodiyanto \& Santoso, 2020) bahwa pembelajaran geometri khsusunya geometri analitik bidang dibutuhkan visualisasi untuk mempermudah dalam memahami materi yang akan dipelajari. Hasil angket pada aspek permasalahan jaringan menunjukkan bahwa $49 \%$ mahasiswa berpendapat bahwa permasalahan terdapat pada jaringan/server. Berdasarkan hasil wawancara menunjukkan bahwa jaringan dalam pembelajaran online merupakan suatu permasalahan karena jaringan di beberapa daerah tidak ada dan bahkan mahasiswa harus ke kota maupun ke bukit untuk mengikuti $e$ learning. Selain itu, 44,9\% mahasiswa setuju bahwa permasalahan terletek pada materi pembelajaran karena materi geometri butuh ilustrasi sehingga pembelajaran online kurang membantu mahasiswa dalam belajar geometri ditambah lagi jaringan yang tidak memadai. Selain itu, masih banyak lagi permasalahan lain yang terjadi pada saat pembelajaran online seperti kehabisan kuota, mahalnya harga kuota bagi keluarga tidak mampu, ketidakmampuan orang tua untuk membeli android yang diharapkan mahasiswa, jaringan terganggu bahkan hilang pada saat bencana (musibah banjir yang saat ini menimpa di beberapa daerah Kalbar seperti Melawi dan Ketapang), dan tugas yang 
menumpuk yang diberikan oleh dosen. Dengan demikian, dapat disimpulkan bahwa selain pembelajaran daring tidak memotivasi mereka (membosankan), materi juga dianggap masalah bagi mahasiswa. Selanjutnya, selain perlu meracang pembelajaran daring yang menarik juga materi pembelajaran juga harus dikemas menarik agar mahasiswa termotivasi dan semangat untuk belajar.

2. Kemampuan pemahaman geometri mahasiswa

Hasil tes kemampuan pemahaman mahasiswa A1 dan A2 pada indikator pemahaman intruksional diperoleh bahwa A1 sudah benar dalam menentukan jarak, tetapi masih salam dalam menentukan nilai akhir pada y yang seharusnya -4 . Berdasarkan hasil wawancara diperoleh bahwa A1 sudah memahasi soal yang diberikan dan mengingat rumus jarak dan titik tengah hanya saja A1 kurang teliti dalam menyelesaikan soal yang diberikan. Berbeda dengan A2, A2 masih salah dalam menentukan nilai $\mathrm{x}$ dan $\mathrm{y}$. A2 mengganggap bahwa $\mathrm{x} 2$ adalah 2 dan $\mathrm{x} 1$ pada titik koordinat $\mathrm{A}(1,2)$ padahal pada titik $A$ memuat $\mathrm{x} 1=1$ dan $\mathrm{y} 1=2$. Demikian pula pada titik B, A2 masih terbalik dalam menentukan nilai dari $\mathrm{x} 2$ maupun y2. Berdasarkan hasil wawancara, A2 mengungkapkan bahwa ia kurang fokus sehingga salah dalam pengambilan nilai dari $\mathrm{x}$ dan $\mathrm{y}$ padahal sudah benar dalam penulisan rumus dari titik tengah maupun jarak. Dari hasil tes kemampuan pemahaman pada pemahaman intruksional dapat disimpulkan bahwa mahasiswa tidak mengalami permasalahan hanya saja butuh konsentrasi dalam menyelesaikan soal walaupun mereka harus lebih banyak lagi dalam menyelesaikan soalsoal untuk memperkuat pemahman mereka. Selain itu, hasil wawancara juga menunjukkan bahwa pembelajaran daring menyebabkan mereka kesulitan dalam memahami materi karena sinyal yang kadang-kadang hilang dan suaran yang kadang-kadang tidak jelas. Hal ini sesuai dengan hasil angket mahasiswa bahwa salah satu permasalahan dalam pembelajaran daring adalah gangguan pada sinyal.

Berdasarkan hasil tes kemampuan pemahaman pada indikator pemahaman fungsional diperoleh bahwa A1 mapun A2 masih kesulitan dalam menyelesaikan soal tersebut. Soal pemahaman fungsional adalah soal yang dikaitkan dengan materi lainnya. Menurut Sumarmo (2010) pemahaman fungsional termasuk kemampuan berpikir tingkat tinggi. Oleh sebab itu, untuk menyelesaikan soal tersebut mahsiswa harus menguasai pemahaman intruksional. Pemahaman instruksional mahasiswa masih belum maksimal sehingga menyebabkan pemahaman fungsional menjadi terhambat. Hal inipun diperkuta dengan hasil wawancara mereka bahwa mereka masih kesulitan dan bingung dalam menentukan titik ujung lainnya pada lingkaran padahal sebenarnya dengan memanfaatkan rumus titik tengah mereka akan menemukan titik ujung lainnya pada lingkaran tersebut (soal 1 pada pemahaman fungsioal). Demikian pula pada sola ke dua, baik A1 maupun A2 masih kebingungan dalam membuktikan apakah titik B berada pada ruang garis AC. Dengan demikian, penyebab lemahnya pemahaman fungsional ini disebabkan lemahnya pemahaman intrumental. Penyebab lemahnya pemahaman intrumental karena sinyal yang kadang-kadang terganggu sehingga pembelajaran tidak maksimal. Hasil penelitian ini juga di dukung dengan temuan (Puspa et al., 
DOI: https://doi.org/10.24127/ajpm.v10i4.4134

2021) bahwa salah satu faktor yang mempengaruhi pemahaman matematis mahasiswa adalah fasilitas yang tidak memadai (jaringan yang tidak normal).

\section{KESIMPULAN DAN SARAN}

Berdasarkan hasil penelitian dan pembahasan maka dalam penelitian ini dapat disimpulkan bahwa (1) mahasiswa lebih suka belajar tatap muka dari pada mengikuti perkuliahan online selama satu semester. Banyak sekali kendala yang dialami mahasiswa selama mengikuti pembelajaran seperti: jaringan yang tidak memadai bahkan banyak di daerah-daerah yang tidak ada signal/jaringan, sulitnya memahami dalam pembelajaran daring, kehabisan kuota, mahalnya harga kuota bagi keluarga tidak mampu, ketidakmampuan orang tua untuk membeli android, jaringan terganggu bahkan hilang pada saat bencana, dan tugas yang menumpuk yang diberikan oleh dosen, dan (2) mahasiswa masih kesulitan dalam menyelesaikan soal kemampuan pemahaman khusunya pada indikator pemahaman fungsional.

Bagi lembaga penyelenggara pendidikan: (1) menginstruksikan kepada setiap dosen agar mengajar sesuai jadwal, (2) menginstruksikan kepada mahasiswa agar berada di Pontianak atau daerah yang signalnya bagus agar bisa mengikuti pembelajaran dengan maksimal. Bagi lembaga pemerintah agar menyediakan jaringan di beberapa daerah yang belum terjangkau signal. Selain itu, memberikan/membelikan android untuk siswa/mahasiswa yang kurang mampu. Bagi peneliti selanjutnya dapat mengembangkan media pembelajaran yang bisa diakses oleh peserta didik sehingga pembelajaran tidak hanya menggunakan zoom, WAG, Google Classroom, Edmodo tetapi lebih menarik dengan adanya media pembelajaran seperti media pembelajaran berbasis adobe flash cs6 yang bisa diakses melalui android dengan mendownload di playstore dan media lain yang mudah diakses mahasiswa.

\section{UCAPAN TERIMA KASIH}

Ucapan terima kasih kami ucapkan kepada IKIP PGRI Pontianak yang telah memberikan dana penelitian ini sehingga penelitian ini bisa dilaksanakan sesuai rencana.

\section{DAFTAR PUSTAKA}

Chandrawati, S. R. (2010). Pemamfaatan E-Learning Dalam Pembelajaran. Jurnal Cakrawala Kependidikan, 8(2), 172-181.

Dewi, W. A. F, . (2020). Dampak COVID-19 terhadap Implementasi Pembelajaran Daring di Sekolah Dasar. Edukatif: Jurnal Ilmu Pendidikan, 2 (1), 55-61.

Enriquez. (2014). Enriquez, M. A. S. (2014). Students 'Perceptions on the Effectiveness of the Use of Edmodo as a Supplementary Tool for Learning. DLSU Research Congress. https://doi.org/10.1017/CBO9781 107415324.004. 2014.

Ghufron, M. . (2018). Revolusi Industri 4.0: Tantangan, Peluang, Dan Solusi Bagi Dunia Pendidikan. Seminar Nasional Dan Diskusi Panel Multidisiplin Hasil Penelitian Dan Pengabdian Kepada Masyarakat 2018, 1(1), 332-337.

Hodiyanto, \& Santoso, D. (2019). Geometer' s Sketchpad ( GSP ) dan Pemahaman Konsep Geometri Analitik Bidang. Jurnal Matematika Kreatif Inovatif. 
DOI: https://doi.org/10.24127/ajpm.v10i4.4134

Hodiyanto, \& Santoso, D. (2020). How Geometer' $s$ Sketchpad ( GSP) Develop $s$ Geometry Concept Understanding. 3(1), 31-35. https://doi.org/10.33122/ijtmer.v3i 1.169

Iftakhar, S. (2016). Google Classroom: What Works And How? Journal of Education and Social Sciences, 3, 12-18.

Irwandani, I., Iqbal, M., \& Latifah, S. (2019). Pengembangan Video Blog (Vlog) Channel Youtube Dengan Pendekatan Stem Sebagai Media Alternatif Pembelajaran Daring. Inovasi Pembangunan: Jurnal Kelitbangan, 7(2), 135. https://doi.org/10.35450/jip.v7i2.1 40

Jamaluddin, D., Ratnasih, T., Gunawan, H., \& Paujiah, E. (2020). Pembelajaran Daring Masa Pandemik Covid-19 Pada Calon Guru: Hambatan, Solusi dan Proyeksi. Karya Tulis Ilmiah UIN Sunan Gunung Djjati Bandung.

Kristanti, R., Isnarto, \& Mulyono. (2019). Kemampuan Pemahaman Konsep Matematis Siswa dalam Pembelajaran Flipped Classroom berbantuan Android. Seminar Nasional Pacasarjana, 618-625.

Kumar, V., \& Nanda, P. (2019). Social media in higher education: A framework for continuous engagement. International Journal of Information and Communication Technology Education, 15(1), 109-120. https://doi.org/10.4018/IJICTE.20 19010108

Moore, J. L., Dickson-Deane, C., \& Galyen, K. (2011). E-Learning, online learning, and distance learning environments: Are they the same? Internet and Higher Education, 14(2), 129-135. https://doi.org/10.1016/j.iheduc.2 010.10 .001

Permendikbud. (2018). Peraturan Menteri Pendidikan Dan Kebudayaan Republik Indonesia Nomor 58 Tahun 2014. Sereal Untuk, 51(1), 51.

Puspa, S. D., Riyono, J., \& Puspitasari, F. (2021). Analisis Faktor-Faktor yang Mempengaruhi Pemahaman Konsep Matematis Mahasiswa dalam Pembelajaran Jarak Jauh Pada Masa Pandemi Covid-19. Jurnal Cendekia: Jurnal Pendidikan Matematika, 5(1), 302-320.

https://doi.org/10.31004/cendekia. v5i1.533

Sicat, A. S. (2015). Enhancing College Students' Proficiency in Business Writing Via Schoology. International Journal of Education and Research, 3(1), 159-178.

So, S. (2016). Mobile instant messaging support for teaching and learning in higher education. Internet and Higher Education, 31, 32-42. https://doi.org/10.1016/j.iheduc.2 016.06.001

Sumarmo, U. (2010a). Berfikir dan Disposisi Matematik: Apa, Mengapa, dan Bagaimana Dikembangkan Pada Peserta Didik. Fpmipa Upi, 1-27.

Sumarmo, U. (2010b). Berpikir Dan Disposisi Matematik: Apa, Mengapa, dan bagaimana dikembangkan pada peserta didik. Bandung: FPMIPA UPI.

Wahid, R., Pribadi, F., Pribadi, F., Wakas, B. E., \& Wakas, B. E. (2020). Digital Activism: Covid19 Effects in Campus Learning. Budapest International Research and Critics in Linguistics and Education (BirLE) Journal, 3(3), 
DOI: https://doi.org/10.24127/ajpm.v10i4.4134

1336-1342.

https://doi.org/10.33258/birle.v3i3

.1174

Wahyono, P., Husamah, H., \& Budi, A. S. (2020). Guru profesional di masa pandemi COVID-19: Review implementasi, tantangan, dan solusi pembelajaran daring. Jurnal Pendidikan Profesi Guru, 1(1), 51-65. http://ejournal.umm.ac.id/index.p hp/jppg/article/view/12462 